УДК $314 / 316,323.2$

$10.17213 / 2075-2067-2021-2-104-120$

\title{
ОБРАЗЫ БУДУЩЕГО В СОЗНАНИИ РОССИЙСКОЙ МОЛОДЕЖИ: ЦЕННОСТНЫЕ ОРИЕНТАЦИИ, ЦИФРОВЫЕ ИННОВАЦИИ И СОЦИАЛЬНО-ПОЛИТИЧЕСКИЕ ОЖИДАНИЯ ${ }^{1}$
}

\author{
(C) 2021 г. В. К. Левашов, О. В. Гребняк, О. П. Новоженина
}

\section{Институт социально-политических исследований Федерального научно-исследовательского социологического центра РАН, 2. Москва, Россия}

Целью социологических исследований, результаты которых обобщаются в статье, являлось изучение представлений российской молодежи об основополагающих принципах и возможных путях развития российского общества и государства, изенностных ориентаичий и сочиально-политических ожиданий.

Методология исследования. В основе анализа лежат соииологические методы. Сбор первичной социологической информации осуществлялся в рамках всероссийского сочиологического исследования «Куда идешь, Россия?», проведенного с участием авторов в декабре 2020 года. Использованы материаль соииологического мониторинга российского общества «Как живешь, Россия?», который проводится с участием авторов на протяжении последних двадиати восьми лет, с отслеживанием динамики постоянно наблюдаемых показателей.

Результаты исследования. Образ будущего в массовом сознании граждан России и отдельных возрастных когорт измерялся с помощью оригинальных сочиологических индикаторов, позволяющих представить структуру фундаментальных убеждений и характер трансформащий суждений и мнений граждан об актуальных сторонах жизни российского общества и его вероятного будущего.

Ключевые слова: образ будущего; сочиальные ожидания; социально-политические иценности российской молодежи; социально-политические риски; устойчивое развитие; общественный консенсус.

\section{IMAGES OF THE FUTURE IN THE CONSCIOUSNESS OF RUSSIAN YOUTH: VALUE ORIENTATIONS, DIGITAL INNOVATION AND SOCIO-POLITICAL EXPECTATIONS}

\section{(C) 2021 V. K. Levashov, O. V. Grebnyak, O. P. Novozhenina}

\section{Institute of Socio-political Research of the Federal Research Sociological Center of the Russian Academy of Sciences, Moscow, Russia}

The purpose of sociological research, the results of which are summarized in the article, was to study the ideas of Russian youth about the fundamental principles and possible ways of development of Russian society and the state, value orientations and socio-political expectations.

1 Исследование выполнено при финансовой поддержке РФФИ и ЭИСИ в рамках научного проекта №20-011-31185. 
Research methodology. The analysis is based on sociological methods. The collection of primary sociological information was carried out within the framework of the all-Russian sociological survey "Where are you going, Russia?», conducted with the participation of the authors in December 2020. The materials of the sociological monitoring of the Russian society "How are you, Russia?», which has been carried out with the participation of the authors over the past twenty-eight years, with tracking the dynamics of constantly observed indicators also were used.

Results of the research. The image of the future in the mass consciousness of Russian citizens and individual age cohorts was measured using original sociological indicators that allow us to represent the structure of fundamental beliefs and the nature of transformations of citizens'judgments and opinions about the current aspects of the life of Russian society and its probable future.

Key words: image of the future; social expectations; socio-political values of Russian youth; socio-political risks; sustainable development; public consensus.

Введение. Проблемная ситуация. Образ будущего как одна из сторон общественного сознания отражает актуальные тенденции жизни общества и связанные с ними представления о социальных, экономических, духовных аспектах будущей жизни. Отношение граждан и в том числе молодежи к сформированному на такой основе образу будущего опирается на базовые социально-политические ценности, существующие в обществе.

Представление об образе будущего, о возможных формах развития общества не может быть ни единственным для общественного сознания в целом, ни неизменным на протяжении времени, как динамична и неоднородна и сама структура базовых социально-политических ценностей граждан, которые оно отражает. Изучение образов будущего отдельных социальных групп и слоев позволяет определить их отношение к актуальной социальной реальности, общественным идеалам и ценностям, к цели общественного развития [1].

Социально-демографическая структура российского общества претерпевает в последние годы значительные изменения. Научно-технический прогресс ведет к сокращению рабочих мест, а пенсионная реформа, начавшаяся в 2018 году, препятствует уходу с рынка труда граждан предпенсионного возраста. Сказываются и низкие темпы роста экономики, а в период коронавирусной пандемии - спад производства. В результате молодежь, выходящую сегодня на рынок труда, с высокой степенью вероятности ожидает ситуативная занятость, неквалифицированный труд, неопределенность и отсутствие перс- пектив продвижения по социальной лестнице. Сложившаяся экономическая ситуация, безусловно, является фактором риска социально-политической устойчивости общества. Росту социальной напряженности способствуют старания несистемной оппозиции вовлечь начинающее трудовую и общественную жизнь поколение в переворот и революцию. В этой связи необходимо активное исследование ценностей и ожиданий, которые складываются у молодежи под влиянием перечисленных факторов, политических, экономических и информационных вызовов, рисков и противоречий, анализ существующих в молодежной среде образов будущего, а также в перспективе выработка конкретных рекомендаций по их формированию.

Настоящая статья подготовлена в процессе разработки основной задачи, стоящей перед исследовательским коллективом проекта «Устойчивость социально-политического развития российского общества и меняющийся образ будущего в массовом сознании граждан», грант РФФИ №20-011-31185. Одним из факторов усиления социально-политической устойчивости общества может стать формирование и поддержание в общественном сознании молодежи аутентичного их ожиданиям убедительного в своей научнорациональной достоверной убедительности образа будущего России.

Актуальные социально-политические ценностные ориентации молодежи. Какие же социально-политические ценности являются сегодня базисными для молодежи 
и как они соотносятся с структурой базисных ценностей других социальных групп и всего общества? Каковы ключевые ценностные ориентации, на которые опирается молодежь, конструируя свой образ будущего? В ходе исследования «Куда идешь, Россия?»² в декабре 2020 года респондентам был задан вопрос: «Какие из перечисленных ниже понятий должны лечь в основу политики развития, независимости и процветания России?». В течение нескольких этапов социологического мониторинга «Как живешь, Россия?» ${ }^{3}$ этот вопрос с таким же набором альтернатив использовался в инструментарии с формулировкой: «В конце XIX — начале XX века правительство России в своей политике опиралось на три понятия: самодержавие, пра- вославие и народность. Какие, по вашему мнению, понятия могли бы лечь в основу политики возрождения России?». Определение композиции идей, которые можно было бы положить в основу массовой политической идеологии - политики возрождения России, показало, что предпочтения респондентов в этом вопросе остаются постоянными на протяжении многих лет. В зависимости от конкретной ситуации на период измерения меняется иерархия понятий, меняется число респондентов, выбравших то или иное понятие, но неизменными в их композиции остаются закон, порядок, справедливость, права человека (см. рис. 1).

Рассмотрим, что отличает структуру ценностных социально-политических
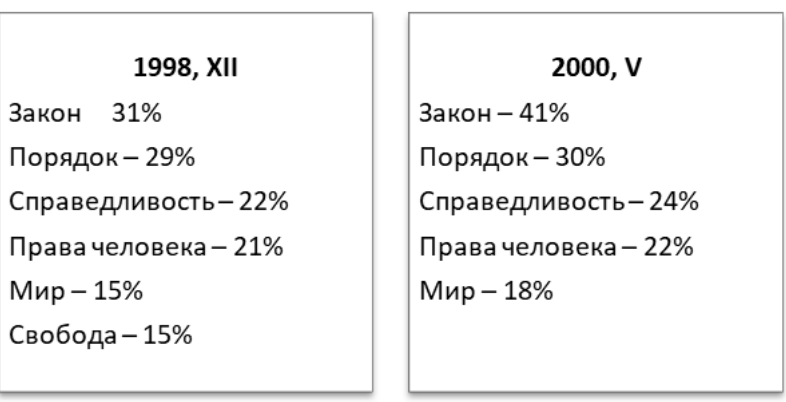
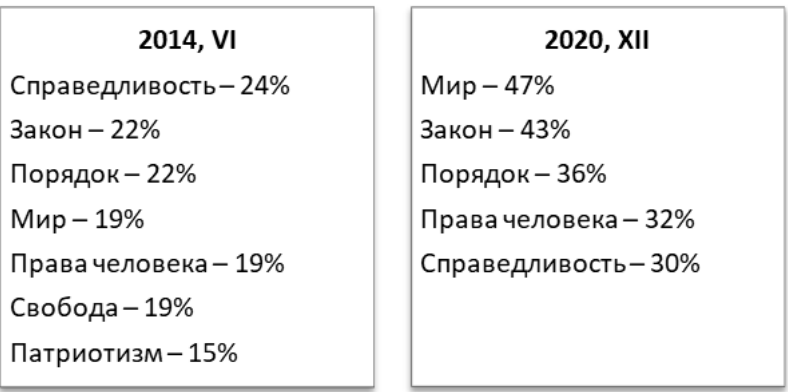

Рис. 1. Структура предпочтений респондентами основных понятий, которые могли бы лечь в основу политики возрождения России, 1995-2020 гг. ${ }^{4}$ (РФ, \% от числа опрошенных)

Примечание: в инструментарии 1995 года позиция «Закон» отсутствовала.

2 Исследование проведено в конце 2020 - начале 2021 гг. в рамках реализации научного проекта «Устойчивость социально-политического развития российского общества и меняющийся образ будущего в массовом сознании граждан». Исследовательский коллектив: д. социол. н. В.К. Левашов (руководитель), д. полит. н. Н.М. Великая, к. социол. н. И.С. Шушпанова, с.н. с. В.А. Афанасьев, м.н. с. О. В. Гребняк, с.н. с. О.П. Новоженина. Полевой этап проходил в ноябре-декабре 2020 г. в 14 регионах РФ. Объем выборочной совокупности составил 1563 респондентов.

3 Социологический мониторинг «Как живешь, Россия?» проводится Центром социальных и социально-политических исследований ИСПИ ФНИСЦ РАН с 1992 г. Научный руководитель мониторинга - д. социол. н. В.К. Левашов. В исследовании использована квотно-пропорциональная всероссийская выборка с взаимозависимыми характеристиками генеральной совокупности: пола, возраста, образования, местожительства. Объем выборочной совокупности составлял на различных этапах 1312-1866 респондентов. Эмпирическим объектом исследования выступает взрослое население России.

4 Источник: Центр социальных и социально-политических исследований ИСПИ РАН. 
ориентаций российской молодежи в конце 2020 - начале 2021 гг. от структуры базисных ценностных ориентаций более старших демографических когорт и всего российского общества (динамика ценностных ориентаций молодежи выходит за рамки данной статьи) (см. табл. 1).

Для проведения анализа в данной статье массив респондентов был сгруппирован по признаку возраста в три группы: молодежь (до 35 лет), средний возраст (36-50 лет) и старший возраст (51 год и более). Выделение в категорию «молодежь» респондентов от 18 до 35 лет обусловлено закреплением соответствующей возрастной группы в Федеральном законе от 30.12.2020 года №489Ф3 «О молодежной политике в Российской Федерации» [3].

В своем анализе мы ограничились рассмотрением тех ценностей, которые получили признание не менее $20 \%$ респондентов в группах либо по всему массиву. Структура и иерархия базовых социально-политических ценностей молодежи в основном сходна с теми, которые разделяет все российское гражданское общество. Однако есть и различия. Для молодежи гораздо большее значение, чем для более старших возрастных когорт, имеют ценности «мир» и «закон». Хотя они находятся на первых местах у всех граждан, только половина респондентов среди молодежи выбрала каждое из них в качестве коренной ценности, которая должна лежать в основе политики возрождения России. И если для респондентов более старших возрастов «закон» и «порядок» находятся на одном уровне значимости - на втором месте (38\% для респондентов среднего возраста, $40 \%$ для старшего), то молодежь ставит «порядок» ниже - на 3-е место (31\%). У молодежи на втором месте находятся «права человека» - 38\%. Гораздо более значимыми, чем для старших когорт, у молодежи являются «свобода» (ее назвали четверть отпрошенных в группе) и «демократия» $(22 \%)$. Доля назвавших «демократию» среди молодежи вдвое превышает долю выбравших ее в более старших группах. Понятие же «державность», выбранное в качестве коренной ценности $20 \%$ и $24 \%$ респондентов старших когорт, имеет гораздо меньшую значимость для молодежи - $17 \%$.
Из представленного в таблице 1 распределения можно заключить, что у граждан, представляющих более старшие и обладающие большим жизненным опытом возрастные группы, снижается представление том, что понятия «мир», «закон», «права человека», а также «свобода», «демократия» могли бы лечь в основу политики возрождения России. Мнение, что таким понятием должна стать «справедливость», сохраняется у трети граждан во всех возрастных группах. А значение категорий «порядок», «патриотизм», «державность» для образа будущего возрождения России у более старших когорт значительно выше.

Отношение граждан и молодежи к цифровым инновациям. Курс на внедрение современных цифровых технологий в различные сферы жизни и производства, заданный Президентом РФ в рамках Послания Федеральному Собранию в конце 2016 года, обусловлен как объективными законами мирового развития, так и назревшей потребностью модернизации российской экономики, необходимостью ухода от догоняющего развития. «Для выхода на новый уровень развития экономики, социальных отраслей нам нужны собственные передовые разработки и научные решения. Необходимо сосредоточиться на направлениях, где накапливается мощный технологический потенциал будущего, а это цифровые, другие, так называемые сквозные технологии, которые сегодня определяют облик всех сфер жизни, применяются во всех отраслях - это цифровые, квантовые, нейротехнологии, робототехника и так далее» [5]. Уровень развития и распространения «цифры» неуклонно растет, особенно после утверждения в конце 2018 года национального проекта «Цифровая экономика», отношение же граждан разных поколений к социальным последствиям внедрения цифровых технологий, как показывают результаты многочисленных исследований экономистов, политологов и социологов, в целом остается неоднозначным.

В ходе исследования «Куда идешь, Россия?» респондентам было предложено выбрать наиболее близкую им позицию по пяти парам высказываний, представляющих собой антонимические суждения о влиянии цифро- 
Таблица 1

Распределение мнений респондентов о понятиях, которые могли бы лечь в основу политики возрождения России (РФ, декабрь 2020 г., \% от числа опрошенных по массиву и в группах. $\mathbf{N}=1563$. Ранжировано по группе «молодежь»)

\begin{tabular}{|c|c|c|c|c|}
\hline & Молодёжь & Средний возраст & Старший возраст & Массив \\
\hline Мир & 50 & 46 & 44 & 47 \\
\hline Закон & 50 & 38 & 40 & 43 \\
\hline Права человека & 38 & 29 & 30 & 32 \\
\hline Порядок & 31 & 38 & 40 & 36 \\
\hline Справедливость & 29 & 31 & 29 & 30 \\
\hline Свобода & 26 & 20 & 18 & 22 \\
\hline Созидание & 23 & 23 & 17 & 21 \\
\hline Демократия & 22 & 13 & 10 & 15 \\
\hline Патриотизм & 21 & 23 & 28 & 24 \\
\hline Державность & 17 & 24 & 20 & 20 \\
\hline Государственность & 15 & 12 & 18 & 15 \\
\hline Частная собственность & 14 & 8 & 7 & 10 \\
\hline Культура & 14 & 12 & 14 & 13 \\
\hline Российская империя & 13 & 16 & 12 & 13 \\
\hline Равенство & 11 & 12 & 9 & 11 \\
\hline Взаимопомощь & 11 & 10 & 11 & 11 \\
\hline Конкуренция & 10 & 8 & 3 & 7 \\
\hline Нравственность & 9 & 14 & 13 & 12 \\
\hline Согласие & 8 & 12 & 10 & 10 \\
\hline Духовность & 7 & 13 & 20 & 15 \\
\hline Капитализм & 7 & 7 & 3 & 6 \\
\hline Интернационализм & 6 & 7 & 4 & 6 \\
\hline Нация & 6 & 5 & 6 & 6 \\
\hline Народовластие & 5 & 4 & 10 & 6 \\
\hline Социализм & 3 & 8 & 14 & 8 \\
\hline Народность & 3 & 2 & 2 & 2 \\
\hline Религиозность & 2 & 4 & 4 & 4 \\
\hline $\mathrm{CCCP}$ & 2 & 3 & 5 & 4 \\
\hline Православие & 2 & 5 & 5 & 4 \\
\hline Братство & 2 & 3 & 1 & 2 \\
\hline Самодержавие & 1 & 1 & 1 & 1 \\
\hline
\end{tabular}

5 Источник: Центр социальных и социально-политических исследований ИСПИ ФНИСЦ РАН. 
вых технологий на качество жизни, уровень обеспечения прав и свобод граждан, на суверенитет страны, на различные сферы физического, морального и духовного развития россиян. Несмотря на принятие и начало реализации федеральных и региональных программ повышения цифровой грамотности для разных возрастных категорий, распределение мнений респондентов о последствиях внедрения цифровых технологий в повседневную жизнь остается традиционным. Молодежь с большей готовностью и оптимизмом воспринимает потенциальные последствия технических инноваций, в то время как у граждан старших возрастных групп преобладает критическое отношение (см. табл. 2, рис. 2).

Возрастная группа «до 35 лет» (молодежь), как видно из таблицы 2, наиболее активна в определении своей позиции, демонстрируя наименьший процент ответов «затрудняюсь ответить» по сравнению с остальными возрастными категориями. У молодежи по всем парам суждений отмечается наиболь- шее число позитивных ожиданий от цифровых инноваций. В то же время наблюдается прямая зависимость между увеличением возраста и нарастанием критически-пессимистических настроений. Респонденты средней возрастной группы (36-50 лет) выраженно отмечают позитивное влияние цифровых технологий по двум направлениям: качество жизни граждан (50\% позитивных ответов против $21 \%$ негативных, 28\% затруднились с ответом) и возможности культурно-ценностного развития (47\% позитивных ответов против 33\% негативных, $21 \%$ воздержавшихся). В отношении воздействия цифровых технологий на уровень гражданских свобод и политического участия респонденты среднего возраста разделились поровну (28\% за рост участия в управлении, $27 \%$ - за снижение прав и свобод граждан). На суверенитет страны и распространенность здорового образа жизни среди населения «цифра», по мнению средней возрастной группы, влияет скорее негативно.
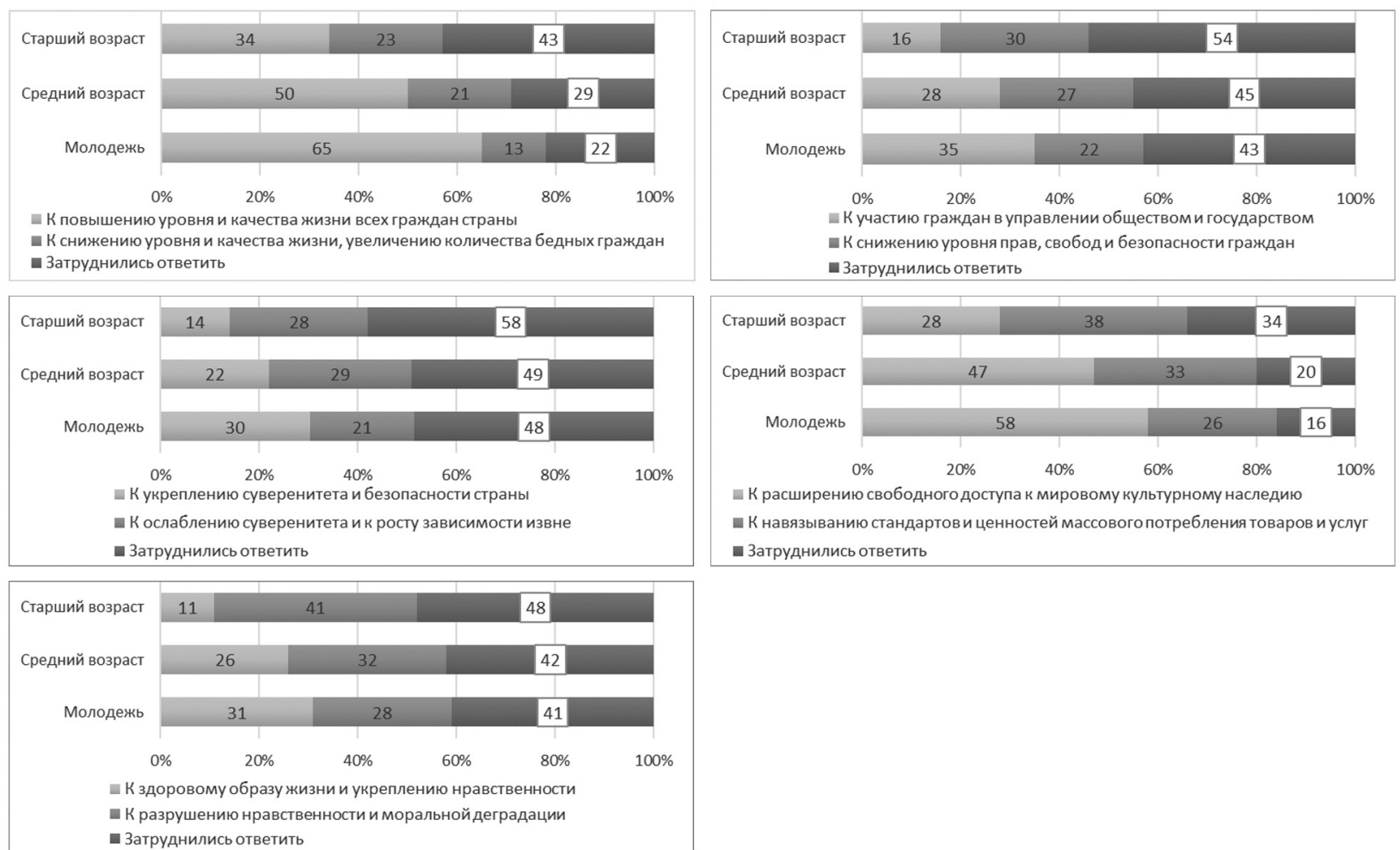

Рис. 2. Распределение мнений респондентов о том, к каким результатам приводит внедрение в нашу жизнь цифровых технологий ${ }^{6}$ (РФ, декабрь 2020 г., \% от числа опрошенных в возрастных группах. $\mathrm{N}=1563$ )

6 Источник: Центр социальных и социально-политических исследований ИСПИ РАН. 
Таблица 2

Распределение мнений респондентов о том, к каким результатам приводит внедрение в нашу жизнь цифровых технологий ${ }^{7}$ (РФ, декабрь 2020 г., \% от числа опрошенных в возрастных группах. $\mathrm{N}=1563$ )

\begin{tabular}{|c|c|c|c|}
\hline Варианты ответов & Молодежь & $\begin{array}{l}\text { Средний } \\
\text { возраст }\end{array}$ & $\begin{array}{l}\text { Старший } \\
\text { возраст }\end{array}$ \\
\hline $\begin{array}{l}\text { к повышению уровня и качества жизни всех граждан } \\
\text { страны }\end{array}$ & 65 & 50 & 34 \\
\hline $\begin{array}{l}\text { к снижению уровня и качества жизни, увеличению коли- } \\
\text { чества бедных граждан }\end{array}$ & 13 & 21 & 23 \\
\hline затруднились ответить & 22 & 29 & 43 \\
\hline Варианты ответов & Молодежь & $\begin{array}{c}\text { Средний } \\
\text { возраст }\end{array}$ & $\begin{array}{c}\text { Старший } \\
\text { возраст }\end{array}$ \\
\hline к участию граждан в управлении обществом и государством & 35 & 28 & 16 \\
\hline к снижению уровня прав, свобод и безопасности граждан & 22 & 27 & 30 \\
\hline затруднились ответить & 43 & 45 & 54 \\
\hline Варианты ответов & Молодежь & $\begin{array}{c}\text { Средний } \\
\text { возраст }\end{array}$ & $\begin{array}{c}\text { Старший } \\
\text { возраст }\end{array}$ \\
\hline к укреплению суверенитета и безопасности страны & 30 & 22 & 14 \\
\hline к ослаблению суверенитета и к росту зависимости извне & 21 & 29 & 28 \\
\hline затруднились ответить & 48 & 49 & 58 \\
\hline Варианты ответов & Молодежь & $\begin{array}{c}\text { Средний } \\
\text { возраст }\end{array}$ & $\begin{array}{c}\text { Старший } \\
\text { возраст }\end{array}$ \\
\hline $\begin{array}{l}\text { к расширению свободного доступа к мировому культур- } \\
\text { ному наследию, научному знанию и сохранению природы }\end{array}$ & 58 & 47 & 28 \\
\hline $\begin{array}{l}\text { к навязыванию стандартов и ценностей массового пот- } \\
\text { ребления товаров и услуг, к деградации природы }\end{array}$ & 26 & 33 & 38 \\
\hline затруднились ответить & 16 & 20 & 34 \\
\hline Варианты ответов & Молодежь & $\begin{array}{c}\text { Средний } \\
\text { возраст }\end{array}$ & $\begin{array}{c}\text { Старший } \\
\text { возраст }\end{array}$ \\
\hline к здоровому образу жизни и укреплению нравственности & 31 & 26 & 11 \\
\hline к разрушению нравственности и моральной деградации & 28 & 32 & 41 \\
\hline затруднились ответить & 41 & 42 & 48 \\
\hline
\end{tabular}

7 Источник: Центр социальных и социально-политических исследований ИСПИ ФНИСЦ РАН. 
У опрошенных старшего возраста (группа «51 год и старше») негативные ожидания от цифровых технологий существенно превышают оптимистичные по всем парам суждений, за исключением последствий для уровня и качества жизни. По данному вопросу 34\% респондентов старше 51 года придерживаются позитивной точки зрения (ведут к повышению уровня и качества жизни граждан), в то время как $23 \%$ считают, что «цифра» приводит к снижению качества жизни и ведет к обеднению граждан. Затруднились ответить $43 \%$ опрошенных старшего возраста.

Таким образом, граждане старшего возраста склонны положительно оценивать цифровые технологии лишь как бытовой инструмент с обширными негативными «побочными эффектами». Респонденты до 35 лет образуют прослойку, склонную верить в положительные последствия цифровизации для страны. Молодежь видит в ней дополнительную возможность влиять на развитие государства и общества, на саморазвитие (расширение культурного и научного кругозора), а также на вопросы экологического характера, занимавшие в 2020 году лидирующие позиции в рейтингах наиболее тревожащих россиян проблем $[2,6]$. Сегодня, как показывают результаты исследования, государство, развивая цифровые технологии, формирует у молодежи позитивные социально-политические ожидания и, как следствие - более оптимистичный, чем у старших поколений, образ будущего.

Что будет завтра, когда наряду с позитивными эффектами ИКТ станут все очевиднее проявляться другие? В научной и общественно-политической литературе они уже получили хлесткие выразительные метафоры «цифровое рабство», «цифровой апартеид», «цифровая тюрьма» и т.п. Молодежь в любые времена в силу своей святой наивности и отсутствия опыта разочарований и ошибок всегда романтизирует научно-технические инновации, не замечает их социально-экономических последствий, которые в современном российском обществе и вне его выражены простой житейской мудростью «богатые богатеют, а бедные беднеют».

СМИ и межличностное общение в формировании образа будущего: мнение респондентов. На фоне рассмотренного выше отношения к цифровым технологиям важно проанализировать динамику картины будущего в зависимости от источника получаемой информации. Картина будущего в сознании граждан складывается из множества факторов внешнего и внутреннего мира личности: фактологического (новости, события), аналитического (наложение актуального и прошлого опыта, общественный дискурс), аксиологического (внутренние моральные и духовные ценностные ориентации и установки) характера. В современном цифровом обществе СМИ как источник массовой информации и межличностное общение в ближнем кругу играют первостепенную роль в формировании образа будущего граждан. На образ будущего в континууме оптимистических и пессимистических рациональных и эмоциональных суждений, оценок, установок граждан в существенной степени влияет общение как в интернете, так и за его пределами.

Традиционные аналоговые и печатные средства массовой информации (телевидение, радио, печатная пресса) продолжают медленно, но неизменно ежегодно терять аудиторию. К примеру, аудитория телевидения за последний год снизилась на 3 п.п., а уровень доверия к нему - на 5 п.п. [4]. В силу этого мы оставим влияние традиционных СМИ на образ будущего за пределами данной статьи, сконцентрировавшись на интернете, получающем все большее распространение в качестве источника информации.

Для изучения расставляемых интернетом акцентов при его воздействии на образ будущего в ходе исследования мы разделили Всемирную паутину на два сегмента. Первый информационный сегмент (сайты сетевых СМИ, официальные сайты компаний и организаций и пр.), второй - общение в социальных сетях. Такое структурирование сети оправдало себя, так как тенденции по сегментам склонны к разнонаправленности, особенно в ответах молодежи (см. табл. 3).

Так общий информационный фон в интернете, по самооценке респондентов, склоняет к пессимистичному взгляду в будущее. Менее пятой части (18\%) опрошенных моложе 35 лет оценивает образ будущего, построенный на информации из интернета, оптимистично. Условных пессимистов вдвое больше - $34 \%$. Еще $48 \%$ респондентов затруднились с оцен- 
кой. На фоне позитивных ожиданий от внедрения цифровых технологий, информация, получаемая из официальных источников в интернете, склоняет молодежь к пессимистичному взгляду в будущее. Сказываются, по всей видимости, наблюдаемые социально-экономические тренды и прогнозы аналитиков относительно сокращения вследствие цифровизации рынка труда, роста цифрового неравенства, угроз кибербезопасности.

Зато общение в социальных сетях дарит скорее оптимизм. У младшего поколения это выражено в большей степени (36\% «оптимис- тичного», 23\% «пессимистичного» образа будущего по внутренней эмоциональной шкале после общения в соцсетях), у среднего и старшего - в меньшей. Респонденты старше 35 лет склонны, скорее, воздержаться от оценки общения в соцсетях (53\% затруднившихся в средней возрастной категории и 72\% - в старшей), однако среди сумевших определиться с ответом респондентов «оптимистичный» взгляд также превалирует, хоть и в минимальной степени.

Системообразующей для позитивного образа будущего в представлении респондентов является семья и близкие (см. табл. 4).

Таблица 3

Распределение ответов респондентов на вопрос:

«Какой образ будущего, оптимистический или пессимистический, возникает у Вас после знакомства с информацией в интернете и общения в социальных сетях 8 (РФ, декабрь 2020 г., \% от числа опрошенных в возрастных группах. $\mathrm{N}=1563$ )

\begin{tabular}{|c|c|c|c|}
\hline \multirow{2}{*}{$\begin{array}{c}\text { Образ будущего при знакомстве } \\
\text { с информацией в интернете }\end{array}$} & \multicolumn{3}{|c|}{ Возраст } \\
\hline & Молодежь & Средний возраст & Старший возраст \\
\hline оптимистический & 18 & 15 & 6 \\
\hline пессимистический & 34 & 31 & 27 \\
\hline трудно сказать & 48 & 54 & 67 \\
\hline \multirow{2}{*}{$\begin{array}{c}\text { Образ будущего после общения } \\
\text { в социальных сетях }\end{array}$} & \multicolumn{3}{|c|}{ Возраст } \\
\hline & Молодежь & Средний возраст & Старший возраст \\
\hline оптимистический & 36 & 25 & 15 \\
\hline пессимистический & 23 & 22 & 13 \\
\hline трудно сказать & 41 & 53 & 72 \\
\hline
\end{tabular}

Распределение ответов респондентов на вопрос:

«Какой образ будущего, оптимистический или пессимистический, возникает у Вас после общения с родственниками и друзьями

(РФ, декабрь 2020 г., \% от числа опрошенных в возрастных группах. $\mathrm{N}=1563$ )

\begin{tabular}{|l|c|c|c|}
\hline \multirow{2}{*}{$\begin{array}{c}\text { Образ будущего после общения } \\
\text { с родственниками и друзьями }\end{array}$} & \multicolumn{3}{|c|}{ Возраст } \\
\cline { 2 - 4 } & Молодежь & Средний возраст & Старший возраст \\
\hline оптимистический & 64 & 60 & 47 \\
\hline пессимистический & 17 & 19 & 22 \\
\hline трудно сказать & 19 & 21 & 31 \\
\hline
\end{tabular}

8 Источник: Центр социальных и социально-политических исследований ИСПИ ФНИСЦ РАН.

9 Источник: Центр социальных и социально-политических исследований ИСПИ ФНИСЦ РАН 
Bсе возрастные группы демонстрируют единодушие в общем настрое и минимальное по ответам на данный блок вопросов число затруднившихся с ответом респондентов (среди молодежи затруднились с ответом лишь 19\% опрошенных). По результатам общения с родственниками и друзьями, подавляющее большинство (64\%) респондентов моложе 36 лет отмечают формирование оптимистического образа будущего в своем сознании. Пессимистические перспективы после общения с семьей отмечают лишь 17\% молодых граждан.

Подводя итоги, следует отметить, что перспективы и возможности цифровизации при всей их неоднозначности дают молодежи надежду на появление возможности изменить свою жизнь к лучшему. Формированию оптимистической картины образа будущего в информационно-коммуникационной сфере в наибольшей мере способствует не столько получаемая из различных источников информация, сколько общение с родными и друзьями.

Социально-политические ожидания российской молодежи. «Социализм» и «капитализм», две базовые системы ценностей и ориентаций находятся в той или иной форме, в большей или меньшей степени в фундаменте всех современных идеологий, в большинстве политических течений. В своем развитии эти два понятия смешиваются и возникают в общественном сознании и в объективной реальности в новых превращенных формах. Они определяют мотивацию труда, политическую культуру, экономическую и финансовую сферы, духовную жизнь общества.

В ходе всероссийского исследования «Куда идешь, Россия?» (декабрь 2020 г.) респондентам был задан вопрос: «Существует два известных понятия: “социализм" и “капитализм". Что каждое из них для Вас означает?». Для ответа был предложен набор альтернатив из понятий, наиболее часто встречающихся в средствах массовой информации и имеющих социально негативный или позитивный смысл. Измерение ответов респондентов различных возрастных когорт и в целом по массиву показало следующие результаты (см. табл. 5).

Анализ распределения ответов по понятию «социализм» показывает, что практичес- ки все альтернативы, указанные представителями группы «молодежь» в первой десятке, являются позитивными: патриотизм $43 \%$, порядок - $40 \%$, коллективизм - $38 \%$, взаимопомощь - $26 \%$, справедливость $25 \%$, нравственность - $22 \%$, технический прогресс - $21 \%$, духовность, права человека - по 19\%. Лишь одна альтернатива из занявших первые десять позиций является негативной - это бедность (21\%). Иерархия категорий, характеризующих понятие «социализм» в представлении молодежи, примерно соответствует структуре мнений, сформировавшихся в обществе. Однако, с точки зрения младшей возрастной группы, такие понятия, как патриотизм, порядок, справедливость, нравственность, технический прогресс в значительно меньшей степени отражают сущность социализма, чем по мнению представителей старших возрастов. Более существенным признаком социализма, в отличие от граждан старшего возраста, они считают бедность.

Картина представлений молодых респондентов о капитализме выдержана, скорее, в негативных тонах - из одиннадцати характеристик, занявших первые десять позиций, восемь - социально негативного или нейтрального содержания: частная собственность $-68 \%$, конкуренция - $63 \%$, власть узкой группы людей - $40 \%$, коррупция $33 \%$, социальная незащищенность - 22\%, подавление личности - $16 \%$, бедность и преступность - по $12 \%$, а три - социально позитивных: технический прогресс - $48 \%$, высокий уровень жизни - 26\%, свобода $23 \%$. Заметим, что позиции социально негативного содержания рассматриваются молодежью как в значительно меньшей степени присущие капитализму, чем в оценках более старших когорт. В противовес этому роль таких позитивных понятий, как технический прогресс, высокий уровень жизни, свобода с точки зрения молодежи гораздо лучше характеризуют капитализм, чем по мнению старших поколений.

Представления о социализме и капитализме формируются в процессе социальной практики, и факторы, которые на них влияют, вполне предсказуемы. Это в первую очередь активное продвижение ценностей капиталистического образа жизни в информационно- 


\section{Операциональные когнитивные представления респондентов}

Таблица 5

о понятиях «социализм» и «капитализм» ${ }^{10}$

(РФ, декабрь 2020 г., \% от числа опрошенных в возрастных группах и по массиву. $\mathbf{N}=1563$. Ранжировано по группе «молодежь»)

\begin{tabular}{|c|c|c|c|c|}
\hline Социализм - это: & Молодежь & Средний возраст & Старший возраст & Массив \\
\hline Патриотизм & 43 & 51 & 52 & 48 \\
\hline Порядок & 40 & 46 & 46 & 44 \\
\hline Коллективизм & 38 & 38 & 38 & 38 \\
\hline Взаимопомощь & 26 & 22 & 33 & 27 \\
\hline Справедливость & 25 & 28 & 32 & 29 \\
\hline Нравственность & 22 & 27 & 26 & 25 \\
\hline Бедность & 21 & 17 & 15 & 18 \\
\hline Технический прогресс & 21 & 23 & 25 & 23 \\
\hline Духовность & 19 & 13 & 22 & 18 \\
\hline Права человека & 19 & 21 & 19 & 20 \\
\hline Народовластие & 17 & 18 & 18 & 18 \\
\hline Гуманизм & 17 & 17 & 21 & 18 \\
\hline Подавление личности & 15 & 11 & 8 & 11 \\
\hline Власть узкой группы людей & 14 & 10 & 8 & 11 \\
\hline Свобода & 12 & 12 & 11 & 11 \\
\hline Высокий уровень жизни & 10 & 13 & 16 & 13 \\
\hline Экономическая отсталость & 8 & 7 & 7 & 7 \\
\hline Социальная незащищенность & 8 & 6 & 5 & 6 \\
\hline Коррупция & 2 & 2 & 1 & 2 \\
\hline Преступность & 1 & 1 & 1 & 1 \\
\hline Частная собственность & 1 & 1 & 1 & 1 \\
\hline Конкуренция & 1 & 1 & & 1 \\
\hline Капитализм - это: & Молодежь & Средний возраст & Старший возраст & Массив \\
\hline Частная собственность & 68 & 63 & 59 & 63 \\
\hline Конкуренция & 63 & 58 & 50 & 57 \\
\hline Технический прогресс & 48 & 43 & 31 & 41 \\
\hline Власть узкой группы людей & 40 & 48 & 48 & 45 \\
\hline Коррупция & 33 & 37 & 49 & 40 \\
\hline Высокий уровень жизни & 26 & 21 & 10 & 19 \\
\hline Свобода & 23 & 13 & 15 & 17 \\
\hline Социальная незащищенность & 22 & 30 & 34 & 28 \\
\hline Подавление личности & 16 & 20 & 24 & 20 \\
\hline Преступность & 12 & 20 & 25 & 19 \\
\hline
\end{tabular}

10 Источник: Центр социальных и социально-политических исследований ИСПИ ФНИСЦ РАН. 
Окончание таблицы 5

\begin{tabular}{|l|c|c|c|c|}
\hline Бедность & 12 & 25 & 34 & 23 \\
\hline Права человека & 11 & 7 & 6 & 8 \\
\hline Порядок & 7 & 4 & 4 & 5 \\
\hline Экономическая отсталость & 5 & 4 & 3 & 4 \\
\hline Коллективизм & 3 & 2 & 2 & 2 \\
\hline Гуманизм & 3 & 2 & 1 & 2 \\
\hline Патриотизм & 3 & 1 & 1 & 2 \\
\hline Народовластие & 2 & 2 & 2 & 2 \\
\hline Справедливость & 2 & 2 & & 1 \\
\hline Духовность & 2 & 1 & 2 & 1 \\
\hline Нравственность & 1 & 1 & & 1 \\
\hline Взаимопомощь & 1 & 0 & & \\
\hline
\end{tabular}

коммуникационном пространстве, по всем каналам массовой информации и коммуникации, от детских мультфильмов до ток-шоу и развлекательных программ, в разнообразных формах, от тщательно дозированной правды до откровенных фейк-ньюс и рассчитанных на различные сегменты аудитории, причем в Конституции РФ декларировано отсутствие государственной идеологии. Кроме того, за прошедшие годы значительно меньше стало тех, кто может реально рассказать о различных сторонах жизни при социализме, не по газетным штампам и информационным вбросам, а из опыта собственной жизни. Свою роль сыграли, конечно, и почтение к экономически более сильным капиталистическим государствам, условиями комфортной жизни и возможностями ведения бизнеса, которые представляются молодежи, вполне достижимыми. С другой стороны, за прошедшие годы либеральных реформ капитализм в нашей стране оборачивался далеко не лучшими своими сторонами к представителям всех возрастных когорт. Получив жизненный опыт, граждане сегодня обладают собственным, основанным на практике, уникальным взглядом на их практическое и смысловое содержание.

Образ будущего отражает представления людей о возможных формах развития общества, в котором они живут. В среде российской молодежи идут сложные процессы социополитической идентификации. В декабре 2020 года $17 \%$ от числа опрошенных респондентов в молодежной группе заявили, что они хотят жить в социалистическом обществе, $29 \%$ - в капиталистическом. Хотят жить в каком-то другом обществе 7\% опро-

Таблица 6

Распределение ответов на вопрос, в каком обществе хотели бы жить респонденты ${ }^{11}$ (РФ, декабрь 2020 г., \% от числа опрошенных в группах и по массиву. $\mathrm{N}=1563$ )

\begin{tabular}{|l|c|c|c|c|}
\hline & Молодежь & Средний возраст & Старший возраст & Массив \\
\hline В социалистическом & $17 \%$ & $26 \%$ & $35 \%$ & $26 \%$ \\
\hline В капиталистическом & $29 \%$ & $24 \%$ & $11 \%$ & $21 \%$ \\
\hline В каком-то другом & $7 \%$ & $4 \%$ & $2 \%$ & $4 \%$ \\
\hline Затруднились ответить & $48 \%$ & $47 \%$ & $52 \%$ & $49 \%$ \\
\hline
\end{tabular}

11 Источник: Центр социальных и социально-политических исследований ИСПИ ФНИСЦ РАН. 
шенных, а почти половина (48\%) затруднились ответить на вопрос (см. табл. 6).

В первую очередь отметим высокую долю как среди молодежи, так и по всему массиву респондентов, затрудняющихся с выбором образа будущего социального устройства
России. Это свидетельствует о том, что российские граждане ищут обновленные социально-политические ориентиры, не видят свое будущее в узком смысловом континууме «капитализм - социализм». Очевидно, что такая ситуация создает угрозы проявления

Распределение ответов респондентов молодежной группы на вопрос: «Как, по Вашему мнению, может измениться положение дел в различных сферах жизни российского общества в ближайшие 5 лет?» с дифференциацией по группам предпочтений ${ }^{12}$

(РФ, декабрь 2020 г., \% от числа опрошенных в группах. $\mathrm{N}=567$ )

\begin{tabular}{|c|c|c|c|c|}
\hline \multicolumn{2}{|c|}{ Сферы жизни общества } & В социалистическом & В капиталистическом & $\begin{array}{c}\text { Затруднились } \\
\text { ответить }\end{array}$ \\
\hline \multirow{3}{*}{$\begin{array}{l}\text { Экономическое } \\
\text { положение } \\
\text { страны }\end{array}$} & станет лучше & 24 & 52 & 42 \\
\hline & не изменится & 44 & 29 & 38 \\
\hline & станет хуже & 32 & 20 & 20 \\
\hline \multirow{3}{*}{$\begin{array}{l}\text { Уровень } \\
\text { жизни } \\
\text { населения }\end{array}$} & станет лучше & 14 & 38 & 36 \\
\hline & не изменится & 54 & 37 & 41 \\
\hline & станет хуже & 32 & 26 & 23 \\
\hline \multirow{3}{*}{$\begin{array}{l}\text { Ситуация } \\
\text { в социальной } \\
\text { сфере }\end{array}$} & станет лучше & 24 & 51 & 49 \\
\hline & не изменится & 48 & 31 & 39 \\
\hline & станет хуже & 29 & 19 & 12 \\
\hline \multirow{3}{*}{$\begin{array}{l}\text { Духовно-нравс- } \\
\text { твенное состоя- } \\
\text { ние общества }\end{array}$} & станет лучше & 14 & 35 & 27 \\
\hline & не изменится & 58 & 52 & 56 \\
\hline & станет хуже & 29 & 14 & 17 \\
\hline \multirow{3}{*}{$\begin{array}{l}\text { Ситуация } \\
\text { в сфере } \\
\text { культуры }\end{array}$} & станет лучше & 14 & 39 & 27 \\
\hline & не изменится & 69 & 50 & 66 \\
\hline & станет хуже & 17 & 12 & 7 \\
\hline \multirow{3}{*}{$\begin{array}{l}\text { Межнацио- } \\
\text { нальные } \\
\text { отношения }\end{array}$} & станет лучше & 42 & 31 & 25 \\
\hline & не изменится & 35 & 54 & 58 \\
\hline & станет хуже & 23 & 16 & 17 \\
\hline \multirow{3}{*}{$\begin{array}{l}\text { Международ- } \\
\text { ное положение } \\
\text { страны }\end{array}$} & станет лучше & 35 & 36 & 36 \\
\hline & не изменится & 41 & 42 & 42 \\
\hline & станет хуже & 24 & 22 & 22 \\
\hline \multirow{3}{*}{$\begin{array}{l}\text { Развитие } \\
\text { демократии }\end{array}$} & станет лучше & 17 & 23 & 17 \\
\hline & не изменится & 53 & 58 & 67 \\
\hline & станет хуже & 29 & 19 & 16 \\
\hline \multirow{3}{*}{$\begin{array}{l}\text { Борьба } \\
\text { с коррупцией }\end{array}$} & станет лучше & 19 & 28 & 19 \\
\hline & не изменится & 47 & 52 & 65 \\
\hline & станет хуже & 35 & 21 & 16 \\
\hline
\end{tabular}

12 Источник: Центр социальных и социально-политических исследований ИСПИ ФНИСЦ РАН. 
фрустраций в различных сегментах общества и приводит к усилению рисков устойчивого развития государства и страны в целом.

Что касается предпочтительных форм социально-политического устройства, то они ожидаемо различны для разных возрастных когорт. Если среди молодежи, определившейся с выбором, исходя из своего видения социализма и капитализма, описанных ранее, наблюдается явное предпочтение капиталистического устройства, то для более старших возрастных групп столь же очевиден выбор в пользу социализма. При половине затруднившихся ответить в группах около трети молодежи желает жить при капитализме, а более трети старшей возрастной группы — при социализме.

Парадоксальной выглядит структура представлений определившихся сторонников социализма и капитализма в группе молодежи о том, как может измениться состояние дел в России в будущем (см. табл. 7).

Сторонники жизни при социализме гораздо более критичны в своих оценках возможных изменений в различных сферах жизни российского общества в ближайшие пять лет, чем их «идейные противники». Только в двух областях - «Межнациональные отношения» и «Международное положение страны» - доля их позитивных ожиданий (42\% и $35 \%$ соответственно) преобладает над негативными (23\% и $24 \%)$, в остальных картина обратная. Доля негативных ожиданий колеблется от $17 \%$ («Ситуация в сфере культуры») до $35 \%$ («Борьба с коррупцией»). В основном же ситуация, по мнению большинства в группе «молодых сторонников социализма», останется неизменной. Так считают от $35 \%$ респондентов («Межнациональные отношения») до 69\% («Ситуация в сфере культуры»).

Сторонники жизни в капиталистическом обществе среди молодежи, наоборот, видят будущее развитие страны в оптимистических тонах. Половина респондентов этой группы считают, что ситуация изменится к лучшему через пять лет в сфере «Экономическое положение страны» и в «Социальной сфере». Среди тех, что предпочитает жизнь при социализме, такой точки зрения придерживаются не более четверти респондентов.

Структура образов будущего развития различных сфер жизни российского обще- ства у той части молодежи, которая не определила свой выбор социально-политического пути, достаточно аморфна, но в ней все же значительно больше позитивных оценок, чем негативных, хотя преобладающей является позиция «ничего не изменится».

Заключение. Образ будущего и резервы консолидации. Консолидировать общество невозможно без наличия образа желаемого будущего. Формирование позитивного образа будущего создает фундамент общественного консенсуса, духовную основу для постановки совместных целей устойчивого развития общества. Социальные ожидания индуцируют и моделируют поведение социальных групп. В обществе образовался явный дефицит политики, основанной на законе, порядке, справедливости, правах человека, мире. По своей общей направленности и содержанию выявленная композиция идей возрождения России хорошо коррелирует с приоритетами ценностей социализма, сложившимися в массовом сознании.

Стремление к закону (правовому государству), справедливости, порядку, правам человека - это те тревожные центры массового сознания, которые сегодня и в будущем будут в значительной степени определять общественную ситуацию в стране, влиять на политический выбор общества и его наиболее чувствительной к переменам и новым веяниям части - молодежи. Сложившаяся матрица понятий имеет достаточно ясный для гражданского сознания аксиологический смысл. Проблемная социально-политическая ситуация требует стимулирования и ускорения процессов социализации молодежи и повышения ее гражданского самосознания. В этой связи целесообразно учитывать проявившиеся особенности и позиционировать смыслы образа будущего в современном гражданском обществе вокруг устойчивого ядра фундаментальных ценностей современного российского общества.

Сложившаяся матрица ценностей имеет достаточно ясный для гражданского сознания аксиологический смысл. Сегодня актуально сложившаяся социально-политическая ситуация требует стимулирования и ускорения процессов социализации молодежи и повышения ее гражданского самосознания. 
В этой связи целесообразно учитывать проявившиеся особенности и позиционировать смыслы образа будущего в современном гражданском обществе вокруг устойчивого ядра фундаментальных ценностей российского общества.

\section{Литература}

1. Желтикова И.В. Исследования будущего и место в них концепта «образ будущего» // Философская мысль. - 2020. №2. - C. 15-32. - DOI: 10.25136/24098728.2020.2.32302.

2. Куда идешь, Россия? Экспресс-информация [Электронный ресурс] / В.К. Левашов, Н.М. Великая, И.С. Шушпанова и др.; отв. ред. В.К. Левашов; ФНИСЦ РАН. - М.: ФНИСЦ PAH, 2021. - 47 c. - DOI 10.19181/monogr 978-5-89697-344-7.2021. — Режим доступа: http:/испи.pф/wp-content/uploads/2021/02/кудаидешь-россия-экспресс.pdf.

3. О молодежной политике в Российской Федерации: Федеральный закон от 30.12.2020 №489-Ф3 [Электронный ресурс] // Официальный интернет-портал правовой информации. - Режим доступа: http://publication.pravo.gov.ru/Document/ View/0001202012300003 (Дата обращения: 10.01.2021).

4. Отчет Deloitte «Медиапотребление в России - 2020», Москва, октябрь 2020 [Электронный ресурс] // Deloitte. - Режим доступа: https://www2.deloitte.com/content/ $\mathrm{dam} /$ Deloitte/ru/Documents/technologymedia-telecommunications/russian/mediaconsumption-russia-2020.pdf (Дата обращения: 11.12.2020).

5. Послание Президента Российской Федерации от 01.12.2016 г. (О положении в стране и основных направлениях внутренней и внешней политики государства) [Электронный ресурс] // Сайт Президента РФ. Режим доступа: http://www.kremlin.ru/acts/ bank/41550 (Дата обращения: 10.01.2021).

6. Экспресс-информация. Как живешь, Россия? 50 этап социологического мониторинга, август-сентябрь 2020 года: (монография) [Электронный ресурс] / В.К. Левашов, Н.М. Великая, И.С. Шушпанова и др.; отв. ред. В.К. Левашов. ФНИСЦ РАН. - М.: Перспектива, 2020. - 64 с. — DOI: 10.19181/mono gr.978-5-88045-463-1.2020. - Режим доступа: http://испи.pф/wp-content/uploads/2020/12/экспресс-информация-как-живешь-россия.pdf.

\section{References}

1. Zheltikova I. $V$. Issledovanija budushhego i mesto V nih koncepta «obraz budushhego» [Studies of the future and the place of the concept «image of the future» in them] // Filosofskaja mysl'. - 2020. - №2. - Pp. 15-32. DOI: $10.25136 / 2409-8728.2020 .2 .32302$.

2. Kuda idesh', Rossija? Jekspress-informacija [Where are you going, Russia? Expressinformation] [Jelektronnyj resurs] / V.K. Levashov, N.M. Velikaja, I.S. Shushpanova et al.; in V.K. Levashov (eds.); FNISC RAN. Moscow: FNISC RAN, 2021. — 47 p. - DOI 10.19181/monogr.978-5-89697-344-7.2021. URL: http://ispi.rf/wp-content/uploads/2021/02/ kuda-idesh'-rossija-jekspress.pdf.

3. O molodezhnoj politike v Rossijskoj Federacii: Federal'nyj zakon ot 30.12.2020 №489FZ [On Youth Policy in the Russian Federation: Federal Law №489-FZ of 30.12.2020] [Jelektronnyj resurs] // Oficial'nyj internet-portal pravovoj informacii [Official Internet portal of legal information]. - URL: http://publication.pravo. gov.ru/Document/View/0001202012300003 (Date accessed: 10.01.2021).

4. Otchet Deloitte «Mediapotreblenie v Rossii — 2020», Moskva, oktjabr' 2020 [Deloitte report «Media Consumption in Russia - 2020», Moscow, October 2020] [Jelektronnyj resurs] // Deloitte. — URL: https://www2.deloitte.com/ content/dam/Deloitte/ru/Documents/technology-media-telecommunications/russian/mediaconsumption-russia-2020.pdf (Date accessed: 11.12.2020).

5. Poslanie Prezidenta Rossijskoj Federacii ot 01.12.2016 g. (O polozhenii v strane $\mathrm{i}$ osnovnyh napravlenijah vnutrennej i vneshnej politiki gosudarstva) [The message of the President of the Russian Federation of 01.12.2016 (On the situation in the country and the main directions of domestic and foreign policy of the state)] [Jelektronnyj resurs] // Sajt Prezidenta RF [Website of the President of the Russian Federation]. - URL: http:/www.kremlin.ru/acts/ bank/41550 (Date accessed: 10.01.2021).

6. Jekspress-informacija. Kak zhivesh', Rossija? 50 jetap sociologicheskogo monitor- 
inga, avgust-sentjabr' 2020 goda: (monografija) [Express information. How do you live, Russia? 50 stage of sociological monitoring, August-September 2020: (monograph)] [Jelektronnyj resurs] / V.K. Levashov, N. M. Velikaja, I.S. Shushpanova et al.; In V.K. Levashov (eds.). FNISC RAN. - Moscow: Perspektiva, 2020. - 64 p. - DOI: 10.19181/monogr.9785-88045-463-1.2020. — URL: http://ispi.rf/wpcontent/uploads/2020/12/jekspress-informacijakak-zhivesh'-rossija.pdf.

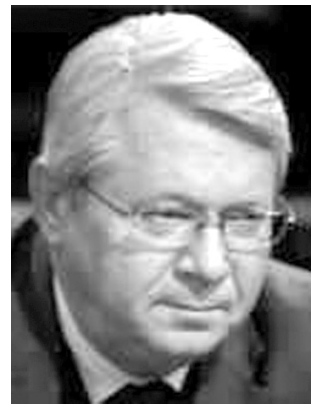

Левашов Виктор Константинович - доктор социологических наук, руководитель Центра социальных и социально-политических исследований, директор обособленного подразделения, Институт социально-политических исследований Федерального научно-исследовательского социологического центра РАН (ИСПИ ФНИСЦ РАН).

Levashov Viktor Konstantinovich - Doctor of Sociological Sciences, Head of the Center of Social and Socio-Political Research, Director of the branch, Institute of Socio-Political Research of the Federal Center of Theoretical \& Applied Sociology of the Russian Academy of Sciences (ISPR FCTAS RAS).

19333, г. Москва, ул. Фотиевой, 6, стр. 1

6 Fotievoj st., bld. 1, 119333, Moscow, Russia

E-mail: levachov@mail.ru

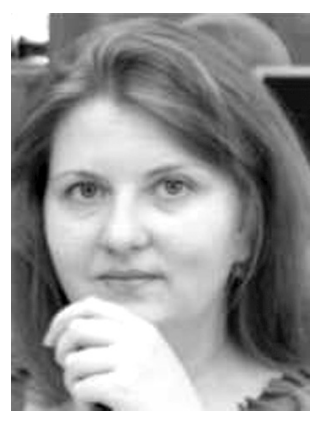

Гребняк Оксана Валерьевна - младший научный сотрудник Центра социальных и социально-политических исследований Института социально-политических исследований Федерального научно-исследовательского социологического центра РАН (ИСПИ ФНИСЦ РАН).

Grebnyak Oksana Valer'evna - Junior Researcher, Center of Social and Socio-Political Research, Institute of Socio-Political Research (ISPR FCTAS RAS).

19333, г. Москва, ул. Фотиевой, 6, стр. 1

6 Fotievoj st., bld. 1, 119333, Moscow, Russia

E-mail: oksananov@yandex.ru 


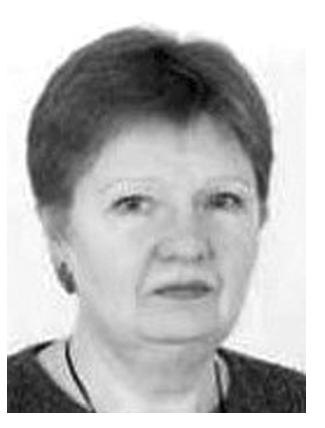

Новоженина Ольга Петровна - старший научный сотрудник Центра социальных и социально-политических исследований Института социально-политических исследований Федерального научно-исследовательского социологического центра РАН (ИСПИ ФНИСЦ РАН).

Novozhenina Olga Petrovna - Senior Researcher, Center of Social and Socio-Political Research, Institute of Socio-Political Research (ISPR FCTAS RAS).

19333, г. Москва, ул. Фотиевой, 6, стр. 1

6 Fotievoj st., bld. 1, 119333, Moscow, Russia

E-mail: olganov@yandex.ru 